\title{
Total Ozone Column Trends over Five Iraqi Selected Provinces Using TOMS Data
}

\author{
${ }^{1}$ Ali M. AL-Salihi, ${ }^{2}$ Zahraa M. Hassan \\ ${ }^{1,2}$ Department of atmospheric Sciences, College of Science / Al-Mustansiriyah University, Baghdad-Iraq
}

\begin{abstract}
Monthly and annual values of the total column ozone(TOC) amount have been analyzed for five stations of Iraq for the period from 1979 to 2012 employing Total ozone Mapping Spectrometer (TOMS) data point, It is found that ozone variation is function of latitude, where the higher values of total ozone column occurs at the northern station which represented by Mosul station, it decreases gradually from northern station (Mosul) passing by middle region stations (Biji, Baghdad and Rutba) to southern station (Basra). The values of Total ozone column start to increase gradually from November to reach its maximum at March then it decreases gradually to reach its minimum values at October. The analysis of the spatial distribution of the monthly average of total ozone column for each month of the year has been made. It is found that the largest of total ozone column amounts occurs systematically over the northern regions during winter whereas in spring and early summer months the maximum values of total ozone column directed to the northwestern regions of the country, The overall period (1979-2012) Trend Analysis presented negative trends for all months in five considered stations except Baghdad station during July and August gives a strong positive trend which refer to a notable enhancement of TOC which reaches to (0.443) DU/Year, Whereas the first period (1979-1992) showed a clear negative trend for all months also for all stations except Baghdad station which presented a weak positive trend during late autumn station, the second period (1997-2012) trends analysis presented negative trends for all months in five considered station except Baghdad station during all months gives a strong positive trend. Finally the results of the second period trend analysis indicated that the ozone layer may be responding as expected to the reducing on ozone-depleting substances imposed by the Montreal Protocol.
\end{abstract}

Keywords: Total ozone column, Atmosphere, TOMS, remote sensing, Iraq.

\section{Introduction}

The decline in stratospheric ozone during recent decades has been well documented; for example, in a series of WMO/UNEP assessments .The main features include the development since the late 1970s of springtime polar ozone depletion over the Antarctic (a depletion which grew most rapidly during the 1980s and early 1990s), an Arctic ozone decline which is most evident in the data from the 1990s, and middle latitude trends which show seasonal variations. Over northern hemisphere $(\mathrm{NH})$ mid latitudes $\left(35-60{ }^{\circ} \mathrm{N}\right)$, the largest ozone decreases are observed during winter/spring, being $4 \%$ below the pre-1980 values over the period $1997-$ 2001, with summer/autumn decreases approximately half as large. Such seasonal variability is not observed over southern hemisphere $(\mathrm{SH})$ mid latitudes, where long-term ozone decreases exhibit a similar magnitude $(6 \%)$ during all seasons [1].

The overall decline of stratospheric total ozone as a man-made perturbation and ozone producing and ozone disturbing processes in the atmosphere is well documented in literature. However, the dynamical contribution to the downward trend in ozone in mid-latitudes is not fully understood. The changes in the stratospheric circulation were a significant factor in the long-term trends of ozone in mid-latitudes. Mcfarlane [2] suggested that up to about $40 \%$ of the observed late winter/early spring trend could be explained by changes in the wave drive of the stratosphere. Additionally, the location of the South Eastern Europe has been addressed for many air pollution studies considering the dense air pollutants in the region and atmospheric flow characteristics. In recent years there has been an increasing anthropogenic process related to human activity, the substantial ozone decrease in spring season over Antarctica are well documented in numerous studies based on various ground and satellite measurements [3- 6]. These studies have shown an overall declining trend of total ozone content globally during the period 1979 - 1993, these studies have led the researcher to monitor TOC trend. After Montreal protocol, efforts were made throughout the globe to reduce the use of ozone depleting chemicals such as Carbone Tetrachloride (CCL), Chlorofluorocarbon (CFC) and Methyl Chloroform ( $\mathrm{CH}_{3} \mathrm{CCL}_{4}$ ) and as a result, the rate of decline of the stratospheric ozone has slowed down [7]. AL-Salihi [8] found a significant reducing of total ozone content in numerous cities such Jeddah, Bahrain, Baghdad, Tehran, Aleppo and Ankara for the period 1979 - 1992. Singh etal,[9] found adecreasing trend of TOC in the northern Indian region compared with other parts of India where the trends is almost stable for the period 1978 - 1993, also they found the effect of El-Nino on TOC for most cities in India, due to which the ozone trend is found to increase during the short period of 1996 - 2000 using ground data and Nimbus-7 Total Ozone Mapping 
Spectrometer (TOMS) data. Demirhan etal [10] discuss the variation in total ozone over southeastern Europe and the Eastern Mediterranean by examining the temporal and spatial variation, they found that the stratospheric ozone in mid-latitude is strongly influenced by lower stratospheric temperature. Attia and Sharobiem [11] have made a verification for TOMS data with those corresponded obtain by Dobson instrument in Cairo, they showed a good correlation between TOMS and Dobson instrument measurements. Sharobiem and Attia [12] found a negative trend through the period $(1985$ - 1995) and positive trend for the period (1995-2000) at Subtropical area. Salihi [13] analyzed time series of TOC using spectral analysis and the power density showed peaks at cycle duration 20, 36 and 40 days. In present paper, we attempt to explain the temporal and spatial TOC employing TOMS data for five stations covered different regions over Iraq.

\section{Total Ozone Column Data}

The NASA Goddard Space Flight Center (GSFC) TOMS instrument is a downward-viewing spectrometer which measures Earth-backscattered UV radiances [14]. The six discrete 1-nm wavelength bands $(312.5,317.5,331.2,339.8,360$, and $380 \mathrm{~nm})$ are measured at 35 scan positions and 3-degree intervals to continuously cover the regions between the orbital paths. The spatial resolution is $50 \mathrm{~km}$ by $50 \mathrm{~km}$ for the nadir view, and about $50 \mathrm{~km}$ by $200 \mathrm{~km}$ at the extreme cross-track scan positions. The TOMS instrument also measures the solar irradiance for each wavelength every day using a diffuser plate to reflect sunlight into the instrument. These solar irradiance measurements are recorded in order to provide radiance normalization and remove some instrumental dependence. TOC data have been derived from the last available version of TOMS algorithm (V.8), which was released in 2004. This backscattered UV algorithm uses only two wavelengths (317.5 and $331.2 \mathrm{~nm}$ ) to derive TOC data, while the other four wavelengths are used for error correction, and identification of aerosols and clouds. In addition, the TOMS algorithm uses the measured albedo at each crosstrack position as input, and a modeled look-up-table. The TOMS instrument was on-board three polar-orbiting sun synchronous satellites from November 1978 until December 2005. The TOC data set has periodic gaps in 1993 and 1994, and there were no data during 1995 and the first half of 1996. In addition, the EP TOMS instrument began to display significant errors by the middle of the year 2000 due to a calibration errors caused by inhomogeneous degradation of its scanner mirror even after on-board correction methods to correct the influence of this instrument degradation, an empirical calibration technique has been applied to the TOC data [15]. Thus, an empirically corrected EP-TOMS TOC data set was released in 2007, showing a remarkable improvement concerning the significant negative bias of around $\sim 3 \%$ detected in the original EP-TOMS V8 data set after the year 2000. In present work the data of TOC investigated during years (1979-1992) and (1997-2012) as first and second time period respectively.

\section{Study Area And Methodology}

Iraq is located in the Middle East; it is the site between the Tigris and Euphrates Rivers, commonly referred to as the Fertile Crescent. The country also borders Jordan, Saudi Arabia, Syria and Turkey. In addition, it borders the Arabian Gulf, with access to the strategic Shatt al Arab waterway, a route excellent for trade and transportation. Iraq's area is a total of 437. $072 \mathrm{sq} \mathrm{km}$ and have a border with Iran 1,458 km, Jordan $181 \mathrm{~km}$, Kuwait $240 \mathrm{~km}$, Saudi Arabia $814 \mathrm{~km}$, Syria $605 \mathrm{~km}$ and Turkey $352 \mathrm{~km}$. The terrain of Iraq is mostly broad plains, with reedy marshes and flooded areas in the south along the Iranian border. Only $13.12 \%$ of Iraqi land is arable with $0.61 \%$ of land used for permanent planting. The climate of Iraq differs depending on the region. Mostly, it is desert, with mild to cool winters and dry, hot, cloudless summers. Central and southern Iraq is characterized by dry, subtropical summers, with temperatures reaching $50^{\circ} \mathrm{C}$. Because the annual rainfall is less than ten inches, agriculture depends primarily on irrigation. The hot and humid climate of southern Iraq, as well as ample water from the two rivers. Some dangers to the farmers in the area include the accumulation of salt brought by irrigation to low-lying areas, sometimes causing desertification. In the north, there is a large mountainous region along the Iranian and Turkish borders. Here, winters are cold with heavy snow that melts in spring and can cause flooding in central and southern Iraq. The flooding often results in destruction of houses and crops for the season. As a result, the central and northern region of Iraq "constantly hovers between desert and swamp.

We select five locations in order to take into account the spatial TOC variability over Iraq. The spatial distribution of these selected locations is shown in Figure 1. It can be seen that the five locations used to quantify the long-term ozone changes over the Iraq are well distributed overall the country, from north to south and from west to east, the five locations are: Mosul $\left(36.19^{\circ} \mathrm{N}, 43.09^{\circ} \mathrm{W}\right)$, Biji $\left(34.55^{\circ} \mathrm{N}, 43.29^{\circ} \mathrm{E}\right)$, Rutba $\left(33.02^{\circ} \mathrm{N}, 40.17^{\circ} \mathrm{E}\right)$, Baghdad $\left(33.21^{\circ} \mathrm{N}, 44.26^{\circ} \mathrm{E}\right)$ and Basra $\left(30.25^{\circ} \mathrm{N}, 47.50^{\circ} \mathrm{E}\right)$. 


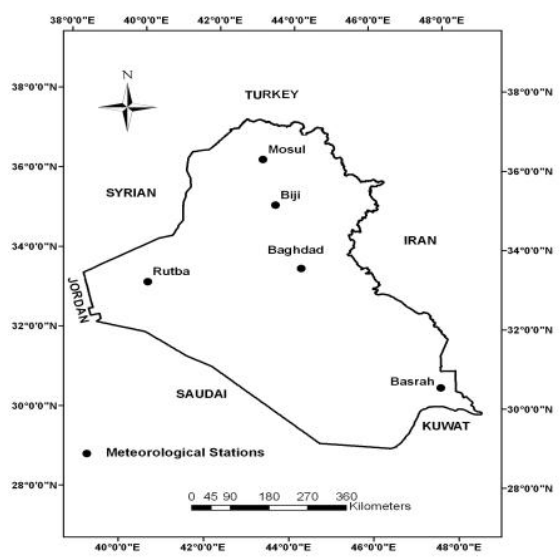

Figure 1: Map of Iraq with the geographical locations of the meteorological stations.

\section{ANNUAL TREND ANALYSIS}

\section{Results And Discussion}

The annual trend analysis of Total Ozone Column (TOC) have been done using Mann Kendall test employing MAKESENS 1.0 free ware for the time series of the annual mean for the period (Overall , first and second ) i.e. for the period (1979-2012, 1979-1992 and 1997-2012) respectively as shown in figure(2) which shows that there is a significant negative trend of TOC depletion in all considered stations particularly during the first period (1979-2012) especially at Mosul and Biji station (- 0.818 and -0.897 DU/ year) respectively, while the second period (1997-2012) presented a relative enhancement for TOC trends particularly at Mosul station which presented a positive trend.
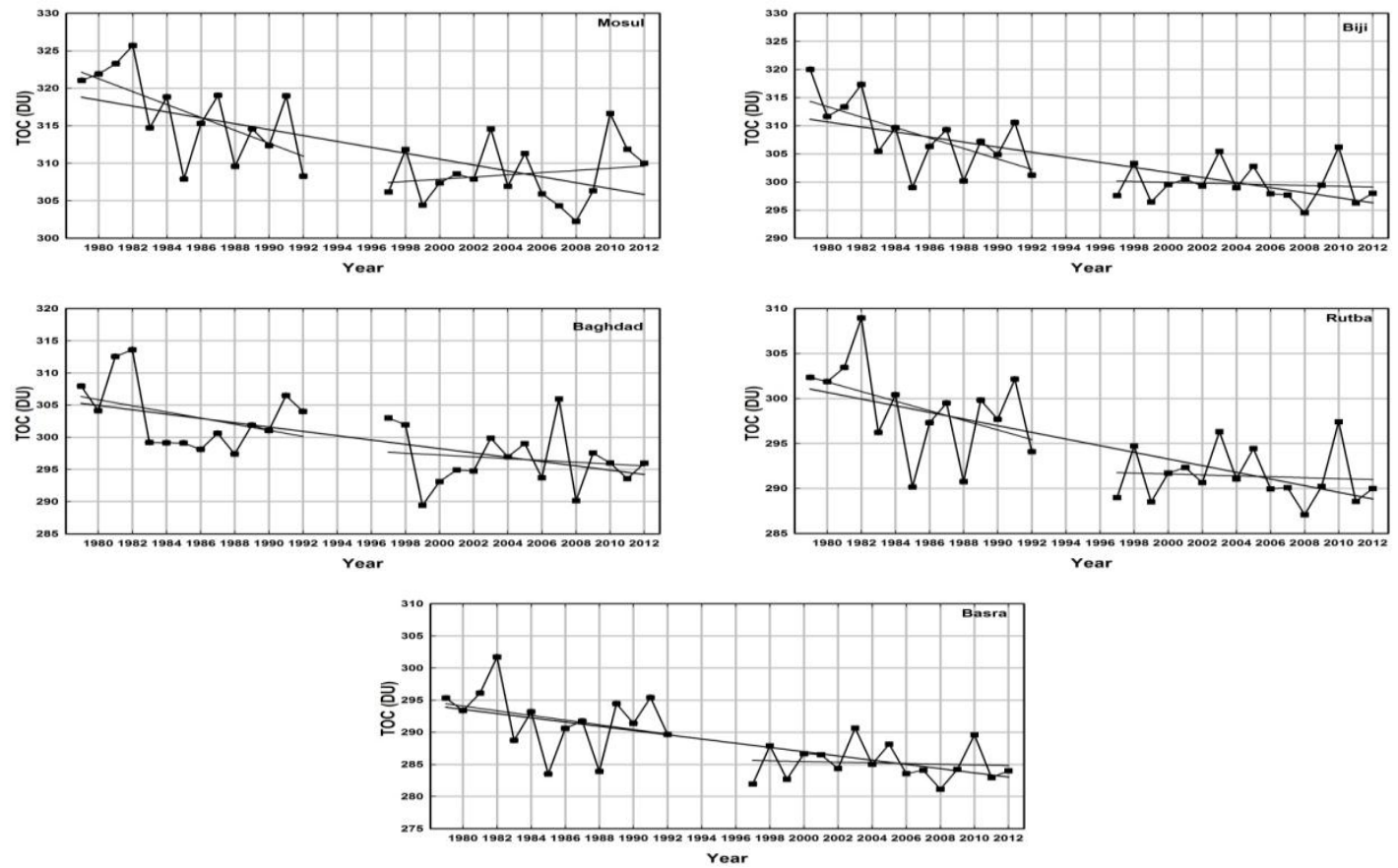

Figure (2) : Annual mean of TOC for considered stations during the period (1979-2012)

\section{MONTHLY TREND ANALYSIS}

Figure (3) shows the time series of TOC over Baghdad station for each month separately through the time period (1979-2012), (1979-1992), (1997-2012). The monthly analysis of TOC for all considered station shows a large variation of TOC Through the year. Where the spring months (March, April, May) have the maximum values of TOC which ranged between (345 and 315 DU) for Mosul and Basra stations respectively. Whereas the Autumn months (September, October, November) which varied between (280 and 259 DU) for Mosul and Basra station respectively which presented the minimum values during the year and this behavior of TOC is familiar in mid-latitude regions. From above result which identify the TOZ behavior and maximum and minimum values the TOZ remains relativity above the permissible limits of TOZ (i.e. 260 DU in mid-latitude regions), whereas on other hands, there are few months when the TOC becomes a values below $260 \mathrm{DU}$ in 
Basra station and this results can be due to the huge gaseous of Carbon dioxide $\left(\mathrm{CO}_{2}\right)$ and particularly Chloroflouro Carbons (CFC's) which is caused by petroleum refinery in Basra city. Trends of TOC over the five considered station has been estimated for each month during the period $1979-2012$. These trends are obtained for the monthly mean values. Table (1) shows the results of the trend analyses and statistically significant trend is evaluated using the $\mathrm{Z}$ and $\mathrm{Q}$ values expressed in Dobson units, respectively. The overall period (1979-2012) Trend Analysis presented negative trends for all months in five considered station except Baghdad station during July and August gives a strong positive trend which refer to a notable enhancement of TOC which reaches to (0.443) DU/Year. Whereas the first period (1979-1992) showed a clear negative trend for all months also for all station except Baghdad station which presented a weak positive trend during late autumn station.The second period (1997-2012) trends analysis presented negative trends for all months in five considered station except Baghdad station during all months gives a strong positive trend also in the (Jan and Feb) months gives positive trends in Mosul and Biji stations.
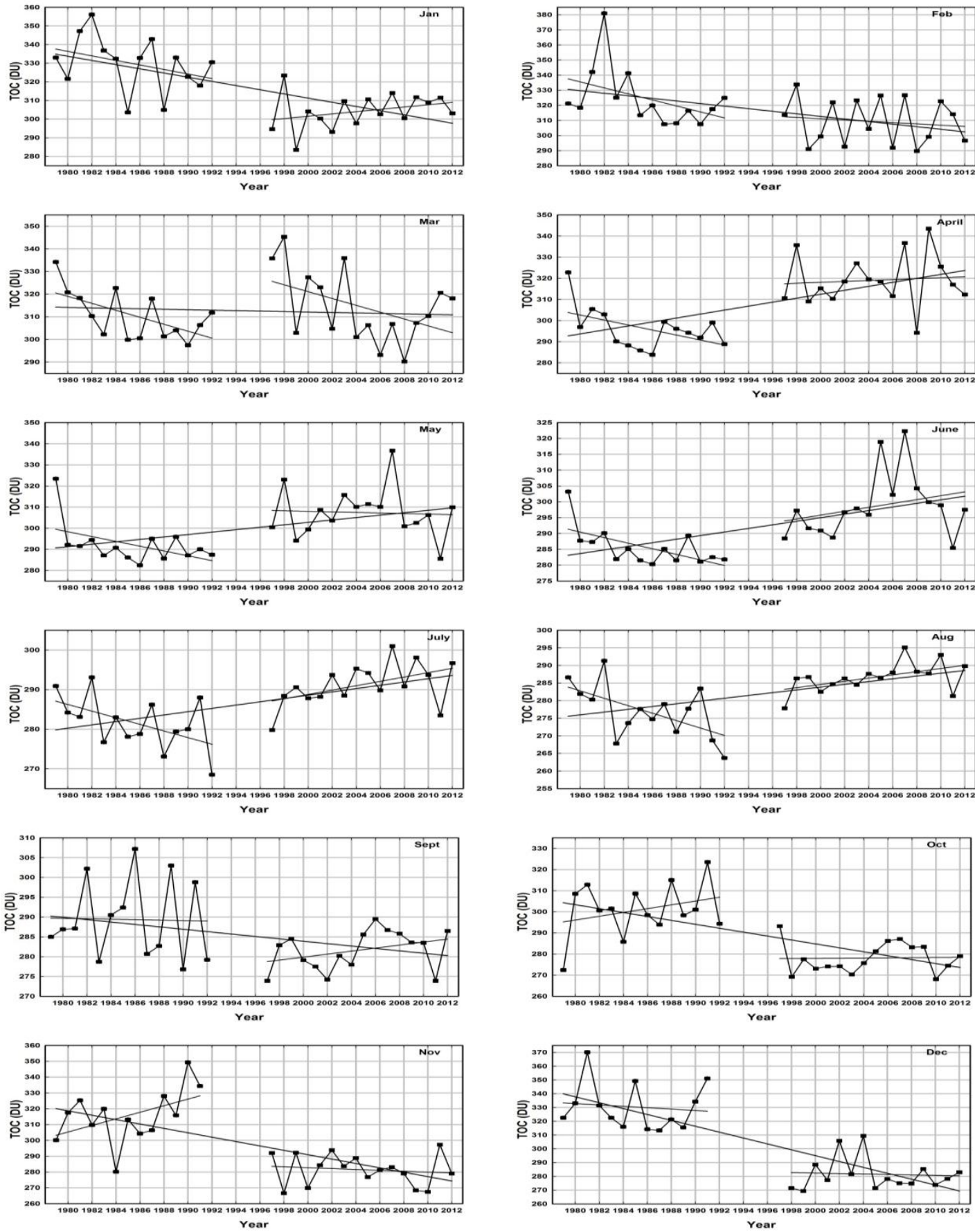

Figure (3): Monthly mean of TOC over Baghdad for each month from January to December for the period (1979-2012). 
Table (1): statistical trend analysis of TOC for Mosul, Biji, Baghdad, Rutba and basra stations.

\begin{tabular}{|c|c|c|c|c|c|c|}
\hline January & \multicolumn{2}{|c|}{$\begin{array}{c}\text { Overall Period } \\
(1979-2012)\end{array}$} & \multicolumn{2}{|c|}{$\begin{array}{l}\text { First Period } \\
(1979-1992)\end{array}$} & \multicolumn{2}{|c|}{$\begin{array}{c}\text { Second Period } \\
(1997-2012)\end{array}$} \\
\hline Station & $\mathbf{Z}$ & Q(DU/year) & $\mathbf{Z}$ & Q(DU/year) & $\mathbf{Z}$ & Q(DU/year) \\
\hline Mosul & -2.59 & -0.568 & -2.08 & -1.900 & 0.09 & 0.127 \\
\hline Biji & -2.37 & -0.500 & -1.75 & -1.646 & 0.45 & 0.329 \\
\hline Baghdad & -3.19 & -1.038 & -1.26 & -1.250 & 1.40 & 0.688 \\
\hline Rutba & -2.57 & -0.500 & -1.64 & -1.367 & 0.23 & 0.181 \\
\hline Basra & -2.64 & -0.448 & -1.48 & -1.033 & 0.00 & -0.030 \\
\hline February & \multicolumn{2}{|c|}{$\begin{array}{c}\text { Overall Period } \\
(1979-2012)\end{array}$} & \multicolumn{2}{|c|}{$\begin{array}{c}\text { First Period } \\
(1979-1992)\end{array}$} & \multicolumn{2}{|c|}{$\begin{array}{c}\text { Second Period } \\
(1997-2012)\end{array}$} \\
\hline Station & $\mathbf{Z}$ & $\mathbf{Q}($ DU/year) & $\mathbf{Z}$ & Q(DU/year & $\mathbf{Z}$ & Q(DU/year) \\
\hline Mosul & -2.96 & -0.735 & -2.36 & -2.086 & 0.14 & 0.117 \\
\hline Biji & -3.00 & -0.689 & -1.86 & -1.471 & 0.14 & 0.181 \\
\hline Baghdad & -2.23 & -0.789 & -1.59 & -1.245 & -0.32 & -0.204 \\
\hline Rutba & -2.69 & -0.647 & -1.31 & -1.000 & 0.32 & -0.268 \\
\hline Basra & -2.52 & -0.556 & -0.99 & -0.885 & 0.36 & 0.396 \\
\hline March & \multicolumn{2}{|c|}{$\begin{array}{c}\text { Overall Period } \\
(1979-2012)\end{array}$} & \multicolumn{2}{|c|}{$\begin{array}{c}\text { First Period } \\
(1979-1992) \\
\end{array}$} & \multicolumn{2}{|c|}{$\begin{array}{c}\text { Second Period } \\
(1997-2012)\end{array}$} \\
\hline Station & $\mathbf{Z}$ & Q(DU/year) & $\mathbf{Z}$ & $\mathbf{Q}($ DU/year) & $\mathbf{Z}$ & Q(DU/year) \\
\hline Mosul & -2.53 & -0.739 & -1.53 & -1.550 & -0.05 & -0.079 \\
\hline Biji & -2.55 & -0.584 & -1.20 & -1.088 & -0.14 & -0.190 \\
\hline Baghdad & -0.25 & -0.083 & -1.75 & -1.500 & -0.86 & -1.431 \\
\hline Rutba & -2.57 & -0.450 & -0.49 & -0.357 & -0.18 & -0.249 \\
\hline Basra & -2.53 & -0.386 & $\begin{array}{l}-0.77 \\
\end{array}$ & -0.458 & $\begin{array}{l}-0.18 \\
\end{array}$ & -0.038 \\
\hline April & \multicolumn{2}{|c|}{$\begin{array}{c}\text { Overall Period } \\
(1979-2012)\end{array}$} & \multicolumn{2}{|c|}{$\begin{array}{l}\text { First Period } \\
(1979-1992)\end{array}$} & \multicolumn{2}{|c|}{$\begin{array}{c}\text { Second Period } \\
(1997-2012)\end{array}$} \\
\hline Station & $\mathbf{Z}$ & Q(DU/year) & $\mathbf{Z}$ & Q(DU/year) & $\mathbf{Z}$ & Q(DU/year) \\
\hline Mosul & -3.43 & -0.600 & -1.31 & -0.590 & -0.59 & -0.337 \\
\hline Biji & -3.03 & -0.510 & $\begin{array}{l}-0.99 \\
\end{array}$ & -0.433 & -0.14 & -0.187 \\
\hline Baghdad & 3.07 & 0.967 & -1.64 & -1.410 & 0.63 & 0.257 \\
\hline Rutba & -2.82 & -0.430 & -0.71 & -0.185 & -0.32 & -0.172 \\
\hline Basra & -2.36 & -0.382 & -0.22 & -0.186 & -0.00 & -0.012 \\
\hline May & \multicolumn{2}{|c|}{$\begin{array}{c}\text { Overall Period } \\
(1979-2012)\end{array}$} & \multicolumn{2}{|c|}{$\begin{array}{l}\text { First Period } \\
(1979-1992)\end{array}$} & \multicolumn{2}{|c|}{$\begin{array}{c}\text { Second Period } \\
(1997-2012)\end{array}$} \\
\hline Station & $\mathbf{Z}$ & Q(DU/year) & $\mathbf{Z}$ & Q(DU/year) & $\mathbf{Z}$ & Q(DU/year) \\
\hline Mosul & -3.80 & -0.726 & $\begin{array}{l}-1.31 \\
\end{array}$ & -0.850 & -0.45 & 0.300 \\
\hline Biji & -3.73 & -0.630 & -1.31 & -0.600 & -0.36 & -0.125 \\
\hline Baghdad & 2.53 & 0.609 & -1.26 & -0.489 & 0.09 & 0.077 \\
\hline Rutba & -3.48 & -0.538 & $\begin{array}{l}-1.04 \\
\end{array}$ & -0.389 & -0.18 & -0.039 \\
\hline Basra & -3.18 & -0.485 & -0.77 & -0.323 & 0.14 & 0.086 \\
\hline June & \multicolumn{2}{|c|}{$\begin{array}{c}\text { Overall Period } \\
(1979-2012)\end{array}$} & \multicolumn{2}{|c|}{$\begin{array}{c}\text { First Period } \\
(1979-1992)\end{array}$} & \multicolumn{2}{|c|}{$\begin{array}{c}\text { Second Period } \\
(1997-2012)\end{array}$} \\
\hline Station & $\mathbf{Z}$ & Q(DU/year) & $\mathbf{Z}$ & Q(DU/year) & $\mathbf{Z}$ & Q(DU/year) \\
\hline Mosul & -3.02 & -0.433 & -0.22 & -0.300 & -0.95 & -0.379 \\
\hline Biji & -2.64 & -0.359 & 0.00 & 0.000 & -0.77 & -0.355 \\
\hline Baghdad & 3.14 & 0.542 & -2.09 & -0.650 & 1.49 & 0.682 \\
\hline Rutba & -2.45 & -0.314 & 0.22 & 0.133 & -0.86 & -0.315 \\
\hline Basra & -2.37 & -0.250 & 0.22 & 0.256 & $\begin{array}{l}-0.99 \\
\end{array}$ & -0.221 \\
\hline
\end{tabular}


Continued

\begin{tabular}{|c|c|c|c|c|c|c|}
\hline July & \multicolumn{2}{|c|}{$\begin{array}{c}\text { Overall Period } \\
(1979-2012)\end{array}$} & \multicolumn{2}{|c|}{$\begin{array}{l}\text { First Period } \\
(1979-1992) \\
\end{array}$} & \multicolumn{2}{|c|}{$\begin{array}{c}\text { Second Period } \\
(1997-2012)\end{array}$} \\
\hline Station & $\mathbf{Z}$ & Q(DU/year) & $\mathbf{Z}$ & Q(DU/year) & $\mathbf{Z}$ & Q(DU/year) \\
\hline Mosul & -3.19 & -0.400 & -0.99 & -0.450 & -1.45 & -0.316 \\
\hline Biji & -3.41 & -0.341 & -0.66 & -0.355 & -1.04 & -0.214 \\
\hline Baghdad & 3.37 & 0.443 & -1.42 & -0.900 & 2.16 & 0.591 \\
\hline Rutba & -2.86 & -0.284 & -0.22 & -0.236 & -0.72 & -0.146 \\
\hline Basra & -2.98 & -0.256 & -0.55 & -0.118 & -0.99 & -0.177 \\
\hline August & \multicolumn{2}{|c|}{$\begin{array}{c}\text { Overall Period } \\
(1979-2012)\end{array}$} & \multicolumn{2}{|c|}{$\begin{array}{r}\text { First Period } \\
(1979-1992)\end{array}$} & \multicolumn{2}{|c|}{$\begin{array}{c}\text { Second Period } \\
(1997-2012)\end{array}$} \\
\hline Station & $\mathbf{Z}$ & Q(DU/year) & $\mathbf{Z}$ & Q(DU/year) & $\mathbf{Z}$ & $\mathbf{Q}$ (DU/year) \\
\hline Mosul & -3.62 & -0.338 & -1.53 & -0.460 & -0.99 & -0.320 \\
\hline Biji & -3.57 & -0.323 & -1.54 & -0.600 & -1.22 & -0.358 \\
\hline Baghdad & 3.34 & 0.421 & -1.86 & -1.200 & 2.52 & 0.457 \\
\hline Rutba & -3.62 & -0.300 & -1.21 & -0.400 & -1.62 & -0.379 \\
\hline Basra & -3.68 & -0.307 & -0.88 & -0.433 & -2.16 & -0.400 \\
\hline $\begin{array}{l}\text { Septemb } \\
\text { er }\end{array}$ & \multicolumn{2}{|c|}{$\begin{array}{c}\text { Overall Period } \\
(1979-2012)\end{array}$} & \multicolumn{2}{|c|}{$\begin{array}{c}\text { First Period } \\
(1979-1992)\end{array}$} & \multicolumn{2}{|c|}{$\begin{array}{c}\text { Second Period } \\
(1997-2012)\end{array}$} \\
\hline Station & $\mathbf{Z}$ & Q(DU/year) & $\mathbf{Z}$ & Q(DU/year) & $\mathbf{Z}$ & Q(DU/year) \\
\hline Mosul & -4.50 & -0.317 & -1.92 & -0.609 & -0.90 & -0.177 \\
\hline Biji & -4.28 & -0.277 & -1.81 & -0.525 & -0.77 & -0.126 \\
\hline Baghdad & -1.34 & -0.189 & 0.00 & -0.256 & 1.35 & 0.404 \\
\hline Rutba & -3.62 & -0.250 & -1.48 & -0.350 & -0.23 & -0.073 \\
\hline Basra & -3.62 & -0.250 & -0.66 & -0.233 & -1.22 & -0.162 \\
\hline October & \multicolumn{2}{|c|}{$\begin{array}{c}\text { Overall Period } \\
(1979-2012)\end{array}$} & \multicolumn{2}{|c|}{$\begin{array}{r}\text { First Period } \\
(1979-1992)\end{array}$} & \multicolumn{2}{|c|}{$\begin{array}{c}\text { Second Period } \\
(1997-2012)\end{array}$} \\
\hline Station & $\mathbf{Z}$ & Q(DU/year) & $\mathbf{Z}$ & Q(DU/year) & $\mathbf{Z}$ & Q(DU/year) \\
\hline Mosul & -2.80 & -0.250 & -0.60 & -0.233 & -0.86 & -0.333 \\
\hline Biji & -3.55 & -0.307 & -0.33 & -0.163 & -1.80 & -0.366 \\
\hline Baghdad & -2.96 & -0.904 & 0.33 & 0.314 & 0.77 & 0.429 \\
\hline Rutba & -3.32 & -0.288 & -0.44 & -0.125 & -1.62 & -0.348 \\
\hline Basra & -3.00 & -0.254 & -0.66 & -0.100 & -1.29 & -0.400 \\
\hline $\begin{array}{c}\text { Novemb } \\
\text { er }\end{array}$ & \multicolumn{2}{|c|}{$\begin{array}{c}\text { Overall Period } \\
(1979-2012)\end{array}$} & \multicolumn{2}{|c|}{$\begin{array}{r}\text { First Period } \\
(1979-1992)\end{array}$} & \multicolumn{2}{|c|}{$\begin{array}{c}\text { Second Period } \\
(1997-2012)\end{array}$} \\
\hline Station & $\mathbf{Z}$ & Q(DU/year) & $\mathbf{Z}$ & Q(DU/year) & $\mathbf{Z}$ & Q(DU/year) \\
\hline Mosul & -2.77 & -0.285 & -2.19 & -0.675 & 0.14 & 0.167 \\
\hline Biji & -2.66 & -0.303 & -2.41 & -1.013 & 0.32 & 0.245 \\
\hline Baghdad & -3.47 & -1.334 & 1.53 & 1.956 & -0.95 & -0.650 \\
\hline Rutba & -2.02 & -0.252 & -1.59 & -0.500 & 0.09 & 0.012 \\
\hline Basra & -2.50 & -0.216 & -1.92 & -0.633 & 0.05 & 0.059 \\
\hline $\begin{array}{c}\text { Decemb } \\
\text { er }\end{array}$ & \multicolumn{2}{|c|}{$\begin{array}{c}\text { Overall Period } \\
(1979-2012)\end{array}$} & \multicolumn{2}{|c|}{$\begin{array}{r}\text { First Period } \\
(1979-1992) \\
\end{array}$} & \multicolumn{2}{|c|}{$\begin{array}{c}\text { Second Period } \\
(1997-2012)\end{array}$} \\
\hline Station & $\mathbf{Z}$ & Q(DU/year) & $\mathbf{Z}$ & Q(DU/year) & $\mathbf{Z}$ & $\mathbf{Q}$ (DU/year) \\
\hline Mosul & -2.25 & -0.414 & -1.64 & -1.100 & -0.49 & -0.164 \\
\hline Biji & -2.14 & -0.344 & -1.53 & -0.883 & 0.00 & 0.000 \\
\hline Baghdad & -3.81 & -1.822 & -0.49 & -0.750 & 0.45 & 0.192 \\
\hline Rutba & -2.19 & -0.284 & -1.31 & -0.578 & 0.00 & 0.029 \\
\hline Basra & -2.53 & -0.275 & -0.11 & -0.157 & 0.00 & -0.033 \\
\hline
\end{tabular}

\section{THE IMPACT OF CFCS EMISSIONS ON TOC DEPILATION}

In order to identify the resulted Total Ozone column recovery which appear in all considered stations. Firstly, we have to understand the Ozone destruction interact which represented by the following. The chemical balance equation of the destruction of Ozone by CFCs as the following equation [16]. 


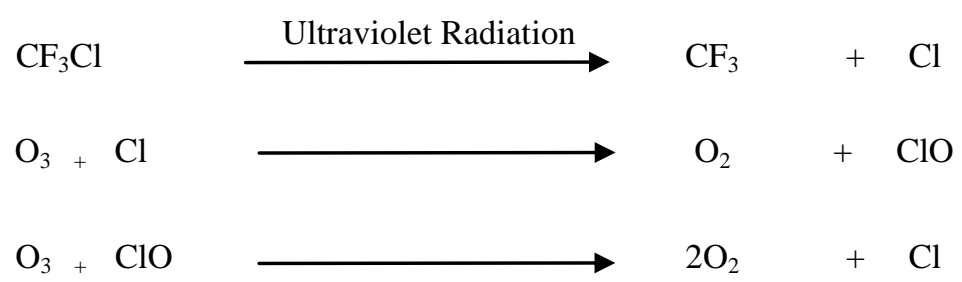

The chemical impact of Total Ozone column destruction interact represented by CFCs gases effect on Total Ozone as shown in equation (1-3).

As a result of Montreal Protocol, the total abundance of Ozone - depleting gases in the atmosphere has begun to decrease in recent years especially during the period after the year 2000. The Montreal Protocol has been successful in slowing and reversing the increase of Ozone depilated gases (halogen source gases) in the atmosphere and the important achievement of this Protocol was success the decreasing in values of effective stratospheric chlorine (CFCs, Halons, HCFs , CCL4, CH3CCL3) as shown in figure (4), all these results were participated on TOZ enhancement and reduce the ozone depletion.
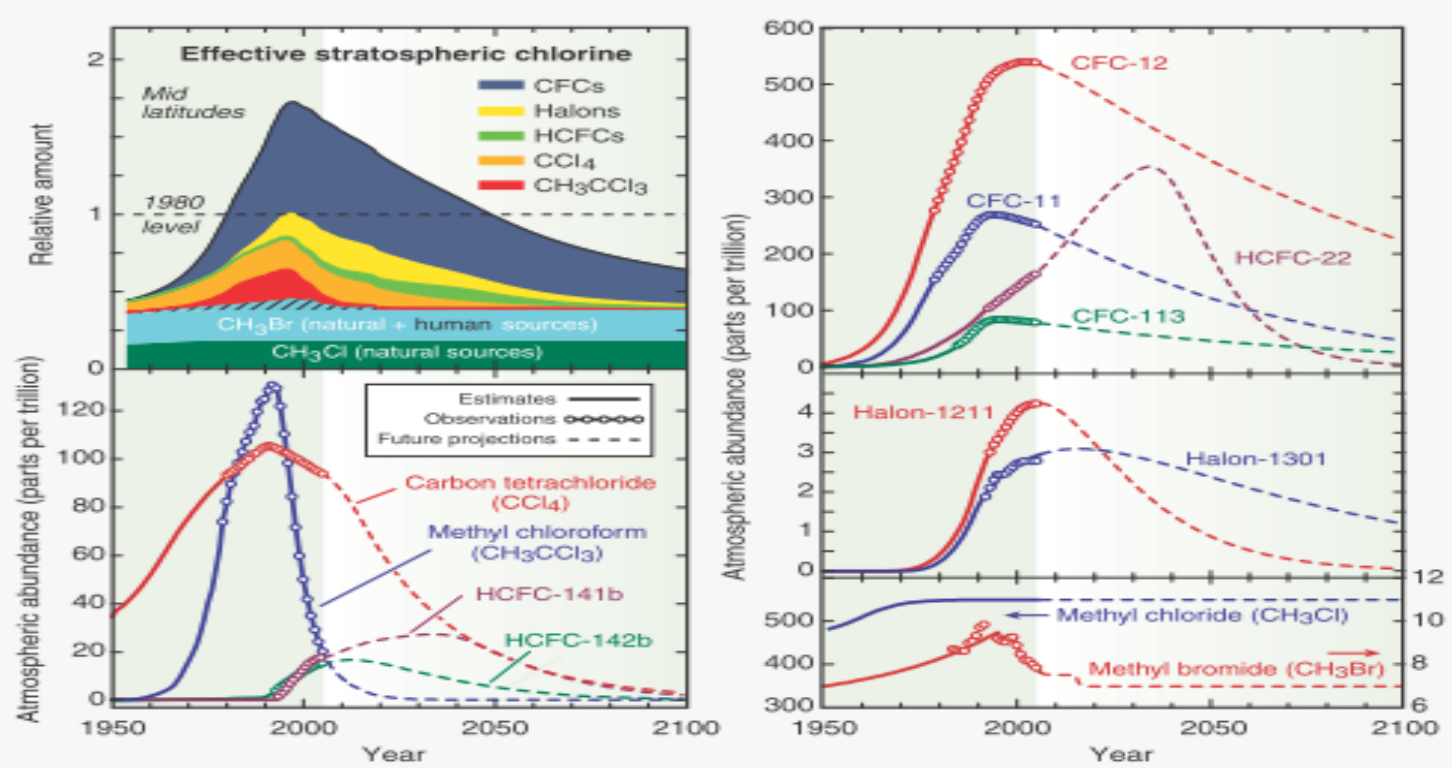

Figure (4): Past and Projected Atmospheric Abundances of Halogen Source Gases.

\section{THE IMPACT OF STRATOSPHERIC TEMPERATURE AND HUMIDITY}

In addition to chemical changes effect on TOC situation on the stratosphere observational data as shown in figure (5) and (6) indicate that the stratospheric temperature at (50 and $70 \mathrm{mb})$ level has been decreased during the last three decades is approximately $(2-3)$ degree. This cooling is attributed to well mixed greenhouse gases (GHGs) including water vapor. The climate change in stratosphere has been affected the rate of Ozone distraction inter act differently at various latitudes, i.e. the stratosphere cooling has been decreased the efficiency of the chemical interact which represented by equation (1), and this has been lead to Ozone recovery during the second period (1997 - 2012) and especially after 2002.

On other hand the effect of relative humidity at $(50$ and $70 \mathrm{mb}$ ) level has been analyzed for the periods $(1979$ - 1992) and (1997 - 2012) as shown in figure (7) and (8), the results shows decreasing of relative humidity during the first period and increasing the relative humidity during the second period (1997 - 2012) which leads to an enhancement in TOC levels, the scientific explanation for this situation is that the increasing of relative humidity means increasing of the amount of water in that level of the atmosphere $(50,70 \mathrm{mb}) \mathrm{which}$ caused an attenuation to the UV radiation by absorption UV by the water vapor and decreasing the UV dose used in disintegration process of CFCs gases as shown in equations (1-3), this will participate in providing a fewer molecules of active chlorine gas that react with Ozone molecules will be a result of this interaction is a molecule of Oxygen and Chlorine dioxide molecule as show in equations (2), and then the resulted chlorine dioxide will interact with other Ozone molecule giving a molecule of chlorine and two Oxygen molecule as shown in equation (3) and this process will continue to destroy 100000 Ozone molecule by one chlorine atom before it is removed from the stratosphere layer. 

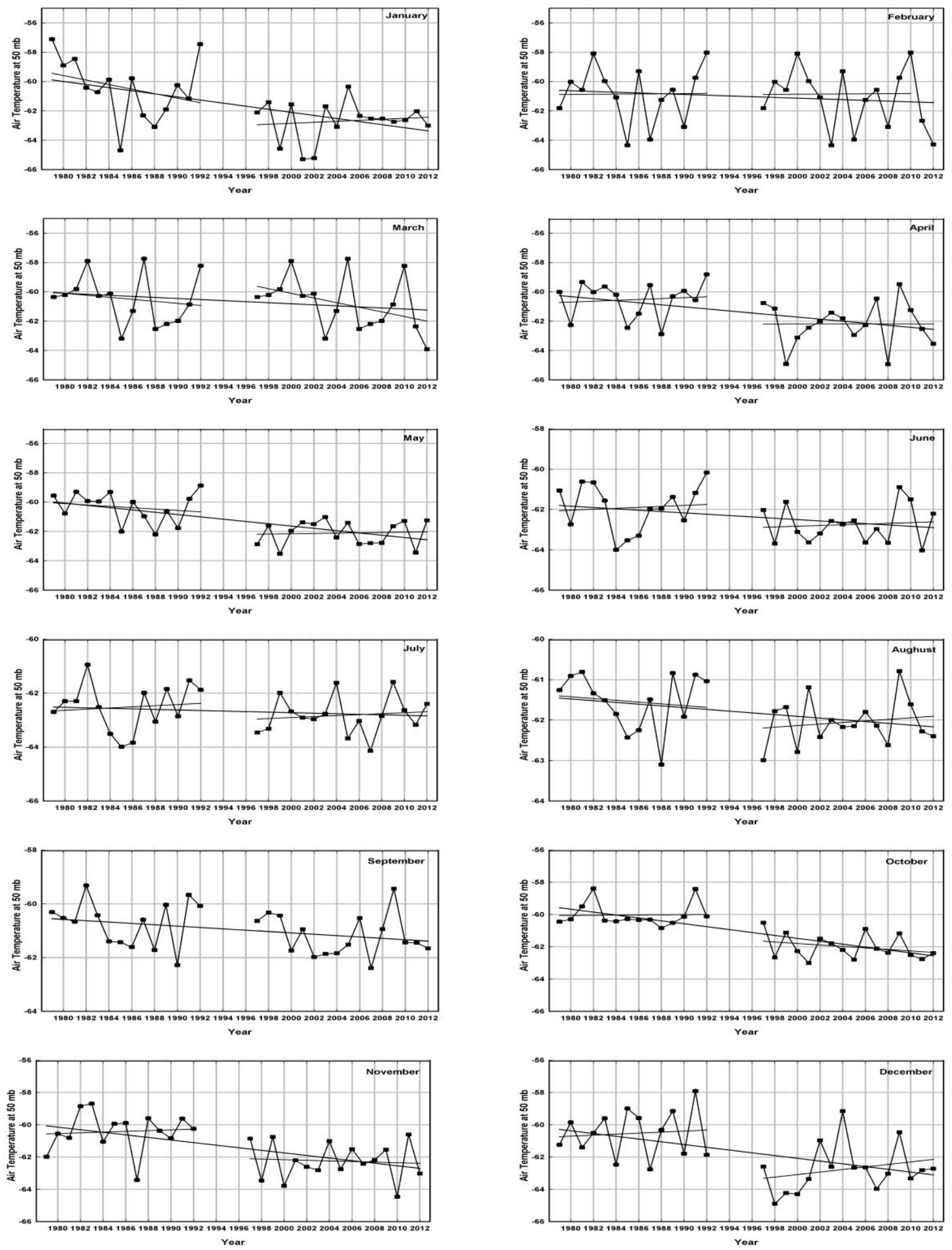

Figure (5): Monthly mean of air temperature at $50 \mathrm{mb}$ over Baghdad for each month from January to December for the period (1979-2012). 

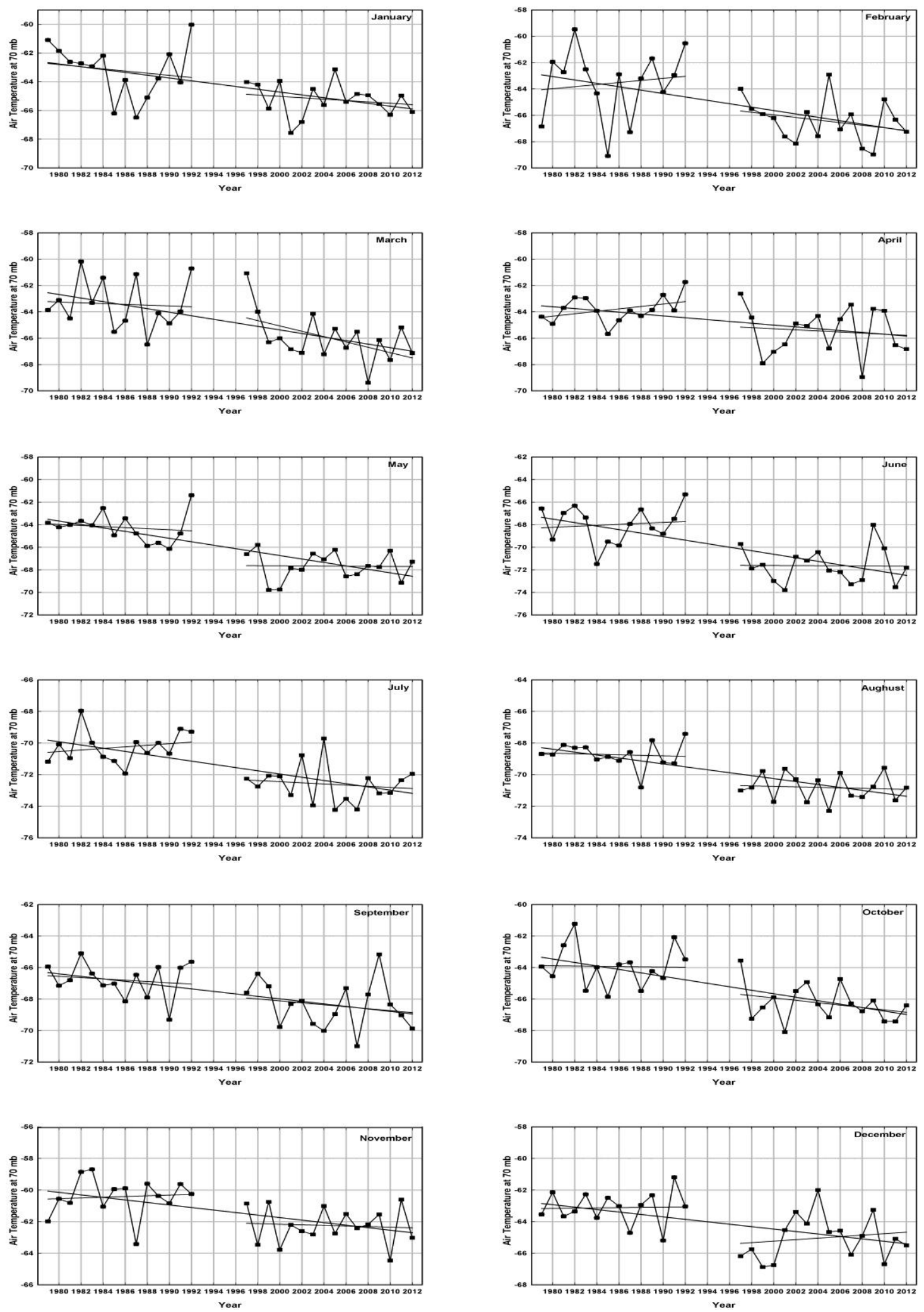

Figure (6): Monthly mean of air temperature at $70 \mathrm{mb}$ over Baghdad for each month from January to December for the period (1979-2012). 

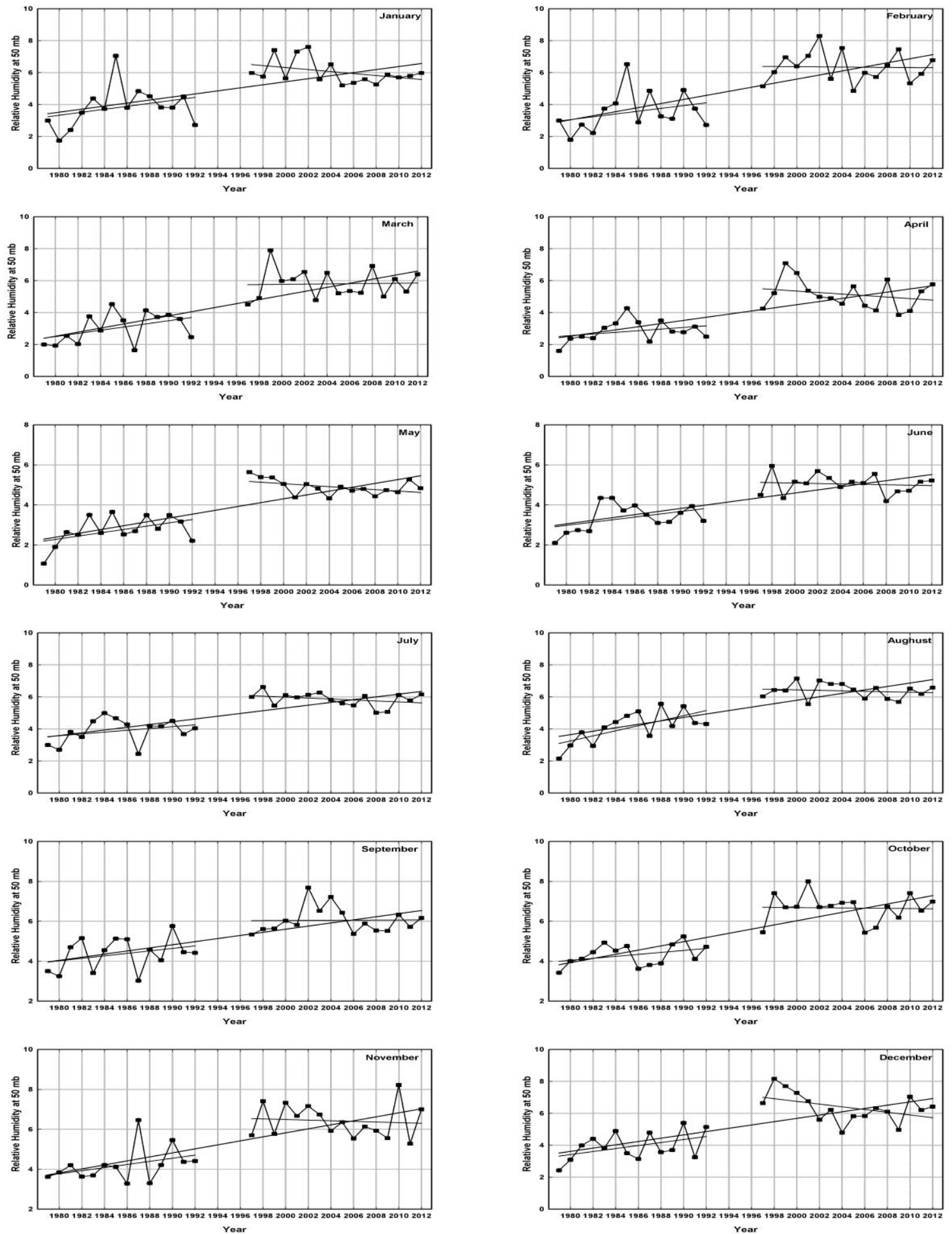

Figure (7): Monthly mean of relative humidity at $50 \mathrm{mb}$ over Baghdad for each month from January to December for the period (1979-2012). 

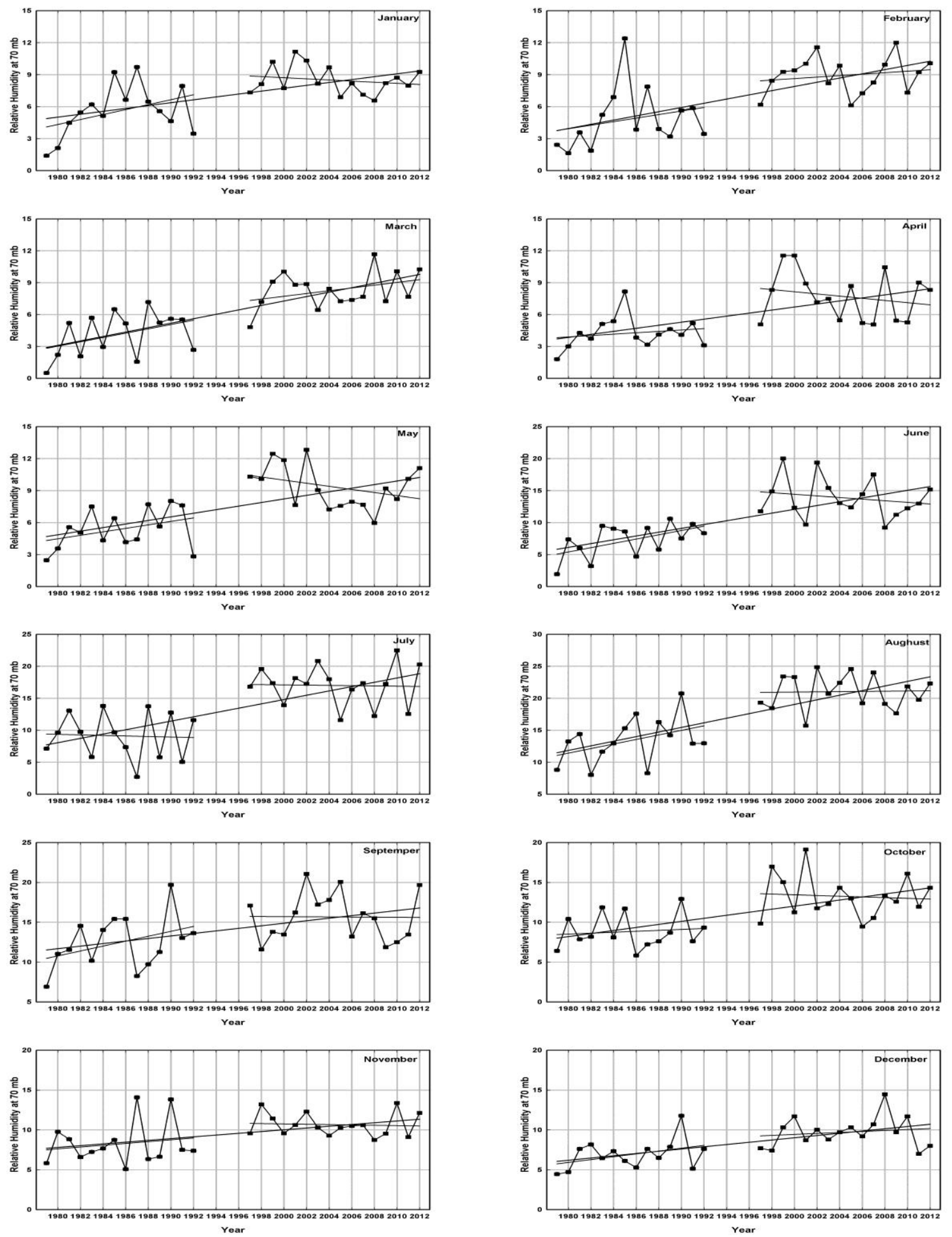

Figure (8): Monthly mean of relative humidity at $70 \mathrm{mb}$ over Baghdad for each month from January to December for the period (1979-2012).

\section{Conclusion}

1. Consider the mentioned results, annual and monthly total ozone column over different cities in Iraq (Mosul, Biji, Baghdad, Rutba and Basra) shows that there is a significant negative trend of TOC values in all considered stations particularly during the first period especially at Mosul and Biji station (- 0.818 and - 
$0.897 \mathrm{DU} /$ year) respectively, while the second period (1997-2012) presented a relative enhancement for TOC trends particularly at Mosul station which presented a positive trend.

2. The monthly analysis of TOC for all considered station shows a large variation of TOC Through the year.

3. Maximum and minimum values the TOC remains relativity above the permissible limits of TOC (i.e. 260 DU in mid-latitude regions).

4. The overall period (1979-2012) Trend Analysis presented negative trends for all months in five considered stations except Baghdad station during July and August gives a strong positive trend which refer to a noticeable enhancement of TOC which reaches to (0.443) DU/Year.

5. The first period (1979-1992) showed a clear negative trend for all months also for all station except Baghdad station which presented a weak positive trend during late autumn season.

6. The second period (1997-2012) trends analysis presented negative trends for all months in five considered station except Baghdad station during all months gives a strong positive trend also Mosul and Biji stations gives positive trends during January and February months.

7. Stratospheric temperature and humidity have a significant impact on TOC levels.

\section{Acknowledgements}

The authors wish to thank NASA Goddard Space Flight Center (GSFC) TOMS instrument for the access to Total Ozone Column data.

\section{REFERENCES}

[1]. World Meteorological Organization (WMO), Scientific Assessment of Ozone Depletion: 2002, WMO Global Ozone Research and Monitoring Project - Report No. 47, 498 pp. Geneva, 2003.

[2]. Mcfarlane, N. 2008, Connections Between Stratospheric Ozone and Climate: Radiative Forcing., Climate Variability and Change., ATMOSPHERE - OCEAN, 46: 139-158

[3]. FIOLETOV, V.E. 2008., Ozone Climatology, Trends and Substances That Control Ozone., Atmosphere - OCEAN, 46: 39-67.

[4]. FRIELER, K., REX, R. J. SALAWITCH, T. CANTY, M. STREIBLE, R. M. STIMPLE, K. PFEILSTICKER, M. DORF, D. K. WEISENSTEIN and S. GODIN - BEEKMANN. 2006, Toward a Better Quantitative Understanding of Polar Stratospheric Ozone Loss., Geophys, Res. Lett. 33: L10812, doi: 10.1029/2005GL025466.

[5]. KERR, J.B. and V.E. FIOLETOV. 2008, Surface Ultraviolet radiation., ATMOSPHERE - OCEAN, 46: 159 - 184

[6]. MCFARLANE, N. 2008, Connections Between Stratospheric Ozone and Climate: Radiative Forcing., Climate Variability and Change., ATMOSPHERE - OCEAN, 46: 139-158.

[7]. FARMAN, J.C., B.J. GARDINER and J.D. SHANKLIN. 1985, Larges Losses of Total Ozone in Antarctica Reveal Seasonal ClOX/ $\mathrm{NO}_{\mathrm{X}}$ Interaction., Nature, 315: 207-210.

[8]. Al-Salihi, A.M., Total Ozone Column Variation Over Baghdad and Selected Cities in Neighbour Countries., Al Mustansiriyah Journal of Science, Baghdad - Iraq, 2009, 20(3), 118-130

[9]. Singh R.P., Sarkar S. and singh A., Effect of El Nino on Inter - Annual Variability of Ozone During The Period 1978-2000 Over The Indian Sub-Continent and China., International Journal of Remote Sensing, 2002, 23, 2449-2456.

[10]. Demirhan D.C., Kahya S. Topcu and S Incecik., Total Ozone Variation in South Eastern Europe., International Journal of Remote Sensing, 2005, 26, 4379-4386.

[11]. Attia A.S., W.M. Sharbiem., Estimation of The Total Amount of Ozone From TOMS Satellite at Cairo., Egypt, Meteological Research Bulletin, 2006, 21, 105-111.

[12]. Sharbiem W.M., E.S. Attia., Variation and Trend of Ozone Total Amount at Tropical and Subtropical Area., Meteorological Research Bulletin, 2006, 21, 93-105.

[13]. Al-Salihi, A.M., Spectral Analysis of Total Ozone Column Variability Using TOMS Data Over Baghdad., Iraq International Journal of Energy and Environment, Volume 2, Issue 2, 2011, pp. 231-236.

[14]. Herman, J. R., D. Larko, 1994, "Nimbus-7/TOMS-November 1, 1978 to May 6, 1993: Low Ozone Amounts During 1992-1993 From Nimbus-7 and Meteor-3 Total Ozone Mapping Spectrometer," J. Geophys. Res., 99, 3483-3496.

[15]. McPeters, R.D., P.K. Bhartia, A.J. Krueger, J.R. Herman, C.G. Wellemeyer, C.J. Seftor, G. Jaross, O. Torres, L. Moy, G. Labow, W. Byerly, S.L. Taylor, T. Swissler, and R.P. Cebula, Earth Probe Total Ozone Mapping Spectrometer (TOMS) Data Products User's Guide. NASA Technical Publication 1998-206895, NASA Goddard Space Flight Center, Greenbelt, Maryland 20771., 1998.

[16]. Valks, P.J.M., and G.J.M. Velders., The Present-day and Future Impact of NOx Emissions from Subsonic Aircraft on The Atmosphere in Relation to The Impact of NOx Surface Sources, Ann. Geophysicae, 17, 1064-1079, 1999. 